Case Report

\title{
Intratubular Spermatocytic Seminomas in 2 Sprague-Dawley Rats
}

\author{
Noriaki Ishigami $^{*}$ and Koji Shimouchi ${ }^{2}$ \\ ${ }^{1}$ Discovery Research Laboratories, Department of Biology \& Pharmacology, Ono Pharmaceutical Co., Ltd., 3-1-1 Sakurai, \\ Shimamoto-cho, Mishima-gun, Osaka 618-8585, Japan \\ ${ }^{2}$ Safety Research Laboratories, Department of Biology \& Pharmacology, Ono Pharmaceutical Co., Ltd., 50-10 Yamagishi, \\ Mikuni-cho, Sakai-shi, Fukui 913-8538, Japan
}

\begin{abstract}
This report describes 2 cases of spontaneous intratubular spermatocytic seminomas in Sprague-Dawley rats. These rats were sacrificed at 10 weeks old (case 1) and 40 weeks old (case 2), respectively. Macroscopically, there were no remarkable changes in either case. Microscopically, tumor cells were observed within a single seminiferous tubule (case 1) or several seminiferous tubules (case 2). The proliferating tumor cells were a tripartite cell population comprising small lymphocyte-like, intermediate-sized or largesized cells, with frequent mitoses, arranged in sheets or forming a basal layer around a tubule or tubules. Immunohistochemically, the tumor cells were strongly positive for proliferating cell nuclear antigen and weakly positive for c-kit, neuron specific enolase and VASA. Our cases provide valuable background control information for the occurrence of seminoma in rats. (DOI: 10.1293/tox.20140005; J Toxicol Pathol 2014; 27: 217-222)
\end{abstract}

Key words: spermatocytic seminoma, seminoma, immunohistochemistry, rat, intratubular

Seminomas are rare neoplasms in rodents that have been incidentally observed in carcinogenicity studies ${ }^{1-7}$. In rats, seminomas have been reported in Fischer-344, Long Evans, Sprague-Dawley and Wistar strains, with most of the animals being about 100 weeks of age ${ }^{1-4,6,7}$. While differential diagnosis of testicular neoplasms and the use of immunohistochemical staining in this context have recently been extensively reviewed in human pathology ${ }^{8-12}$, immunohistochemical research is extremely rare in rodents ${ }^{3,6}$. Here, we report 2 cases of intratubular spermatocytic seminomas that occurred as incidental findings in relatively young SpragueDawley rats with details of their histological and immunohistochemical characteristics.

The animals were 10- and a 40-week-old male SpragueDawley [Crl:CD(SD), Charles River Laboratories Japan, Inc. (Kanagawa, Japan)] rats from a 4-week toxicity study (case 1 , compound A) and an 8-week recovery group of a 26 -week toxicity study (case 2, compound B), that had been submitted for scheduled sacrifice, respectively. The animals were housed in a wire mesh cage in an animal room under controlled conditions (temperature, $23 \pm 3^{\circ} \mathrm{C}$; relative humidity, $50 \pm 20 \%, 12$-h light/dark cycle) and given ad libitum access to CRF-1 diet (Oriental Yeast Co., Ltd., Tokyo, Japan)

Received: 3 February 2014, Accepted: 14 May 2014

Published online in J-STAGE: 9 June 2014

*Corresponding author: N Ishigami (e-mail: ishigami@ono.co.jp)

(C2014 The Japanese Society of Toxicologic Pathology

This is an open-access article distributed under the terms of the Creative Commons Attribution Non-Commercial No Derivatives (by-ncnd) License $<$ http://creativecommons.org/licenses/by-nc-nd/3.0/>. and tap water. The animals were handled in accordance with the Guidelines for Animal Experimentation issued by Ono Pharmaceutical Co., Ltd., which are based on the guidelines for animal experimentation issued by the Japanese Association for Laboratory Animal Science.

The testes and epididymides were prefixed in formalin sucrose acetic acid (FSA) solution for 5 days, and then the tissues were transferred into $10 \%$ neutral buffered formalin; the other sampled systemic organs and tissues were also fixed in $10 \%$ neutral buffered formalin, embedded in paraffin, sectioned at $4 \mu \mathrm{m}$ and stained with hematoxylin and eosin (HE). In addition, in case 1, serial sections of testes were stained with periodic acid-Schiff (PAS) and for immunohistochemistry with c-kit, cytokeratin (AE1/AE3), DDX4 (VASA), neuron specific enolase (NSE), placental alkaline phosphatase (PLAP), podoplanin, proliferating cell nuclear antigen (PCNA), S100 and vimentin. The primary antibodies and key reagents used for immunohistochemistry are listed in Table 1. A universal immunoenzyme polymer method (N-Histofine Simple Stain Max PO (M) or (R), Nichirei Corp., Tokyo, Japan) or the labeled streptavidinbiotin method with an LSAB2 kit (Dako Japan) was used for immunoreactions. The sections were developed with a diaminobenzidine hydrogen peroxidase substrate and counterstained with hematoxylin.

In the right testis of case 1, tumor cells with distinct cell boundaries were confined within a single seminiferous tubule and arranged in sheets or formed a basal layer around the tubule displacing the Sertoli cells toward the tubular lumen (Fig. 1A). On closer inspection, the proliferating tumor cells were a tripartite cell population comprising small lym- 
Table 1. Primary Antibodies and Reaction Conditions for Immunohistochemistry

\begin{tabular}{lllll}
\hline Antibody & Source* & Clone (code) & Dilution & Antigen retrieval \\
\hline c-kit & Dako US & (A4502) & $1: 100$ & Citrate buffer, pH 9 \\
Cytokeratin & Dako US & AE1/AE3 (Z0622) & $1: 800$ & Proteinase K \\
VASA & Abcam & (ab13840) & $1: 200$ & Citrate buffer, pH 6 $6^{* *}$ \\
NSE & Nichirei & $(422081)$ & Ready-to-use & None \\
PLAP & Dako DK & 8A9 (M7191) & $1: 100$ & Citrate buffer, pH 9 ${ }^{* *}$ \\
Podoplanin & AngioBio & $(11-035)$ & $1: 100$ & Proteinase K \\
PCNA & Dako DK & PC10 (M0879) & $1: 6000$ & Tris/EDTA buffer, pH 9 $9^{* *}$ \\
S100 & Dako DK & (Z0311) & $1: 1600$ & None \\
Vimentin & Dako DK & V9 $($ M0725) & $1: 600$ & Tris/EDTA buffer, pH 9 $9^{* *}$ \\
\hline
\end{tabular}

* Dako US (Carpinteria, CA, USA); Nichirei (Nichirei Biosciences, Tokyo, Japan); Dako DK (Denmark A/S, Glostrup, Denmark); AngioBio (Del Mar, CA, USA); Abcam (Cambridge, MA, USA).

** Antigen retrieval was conducted by pressure-cooker heating (Pascal, Dako).

Table 2. PAS and Immunohistochemical Staining in the Germ Cell and Germ Cell Neoplasia

\begin{tabular}{|c|c|c|c|c|c|c|c|c|c|c|c|}
\hline & PAS & c-kit & NSE & VASA & PLAP & PP & VIM & $\mathrm{CK}$ & S100 & AFP & hCG \\
\hline \multicolumn{12}{|l|}{ Human $^{8,9,19-30}$} \\
\hline \multicolumn{12}{|l|}{ Normal adult } \\
\hline Spermatogonia & - & $\mathrm{v}$ & + & + & - & - & - & - & - & - & - \\
\hline \multicolumn{12}{|l|}{ Germ cell tumor } \\
\hline IGCNU & + & + & + & + & + & + & - & - & - & - & - \\
\hline Seminoma & + & + & + & $\mathrm{v}$ & + & + & $\mathrm{v}$ & $\mathrm{v}$ & - & - & - \\
\hline Spermatocytic seminoma & - & $\mathrm{v}$ & $\mathrm{v}$ & + & $\mathrm{v}$ & - & - & - & - & - & - \\
\hline \multicolumn{12}{|l|}{ Rat } \\
\hline \multicolumn{12}{|l|}{ Normal adult ${ }^{\#}$} \\
\hline Spermatogonia & - & + & - & - & - & - & - & - & - & NA & NA \\
\hline Spermatocyte & - & - & - & - & - & - & - & - & - & NA & NA \\
\hline \multicolumn{12}{|l|}{ Tumor } \\
\hline Case 1 & - & $+/-$ & $+/-$ & $+/-$ & - & - & - & - & - & NA & NA \\
\hline Seminoma $^{3}$ & - & NA & NA & NA & NA & NA & + & - & + & - & NA \\
\hline Intratubular spermatic seminoma ${ }^{6}$ & NA & NA & - & NA & NA & NA & - & + & + & - & - \\
\hline
\end{tabular}

IGCNU, intratubular germ cell neoplasia, unclassified; \#, internal control of case 1; PP, podoplanin; VIM, vimentin; CK, AE1/AE3; AFP, $\alpha$-fetoprotein; hCG, human chorionic gonadotropin;-, negative; +--, weakly positive; +, positive; NA, not applicable; v, variable.

phocyte-like, intermediate-sized or large-sized cells characteristic of spermatocytic seminoma (Fig. 1B). The small cells had hyperchromatic nuclei and lacked nucleoli. The intermediate cells formed the predominant population with a round to polygonal nucleus, often with a granular chromatin pattern and an inconspicuous nucleolus. The large cells either had a single large nucleus or, although rarely, multiple nuclei, with small nucleoli. Tumor cells had scant pale eosinophilic cytoplasm. Mitotic figures were numerous. The central region of the tubule contained an aggregate of Sertoli cells and a small number of spermatozoa. Staining with PAS for glycogen was generally negative. Immunohistochemically, most of the tumor cells were weakly positive for c-kit (Fig. 2A), NSE (Fig. 2B) and VASA (Fig. 2C) but negative for PLAP, S100, vimentin, AE1/AE3 and podoplanin (Table 2). The tumor cells also showed a high PCNA labeling index (Fig. 2D). In normal seminiferous tubules (examined using testes from an internal control Sprague-Dawley rat, 10-weeks old), spermatogonia and Sertoli cells stained positive for c-kit and vimentin, respectively, and both cells were positive for PCNA. Using the same 10-week-old control testes, germ cells were negative for VASA, but in early puberty (examined using testes from 6-week-old rats), the cytoplasm of the spermatogonia and spermatocytes stained weakly positive and positive, respectively, although rarely (data not shown). No apparent intertubular proliferations, invasions or metastases were found.

In case 2, the tumor affected several adjacent seminiferous tubular profiles in the right testis. The tumor-bearing seminiferous tubules showed intratubular sheet-like proliferation (Fig. 3A). Tumor cells contained three cell populations, including small-, medium- and large-sized tumor cells. The predominant cell type was medium in size. The medium- to large-sized and multinucleated giant tumor cells had round to polygonal large nuclei with a granular to stippled chromatin pattern and large prominent nucleoli. These anaplastic tumor cells showed numerous mitotic figures (Fig. 3B). Moreover, closely aggregated anaplastic tumor cells that appeared to be extending into the peritubular layer were found adjacent to one of the affected tubules (Fig. $3 \mathrm{C})$. These tubules were surrounded by macrophages and contained erythrocytes and spermatozoa. Neither prominent invasion nor metastases were observed. Also, many atrophic/regenerative tubules were detected in both testes, 

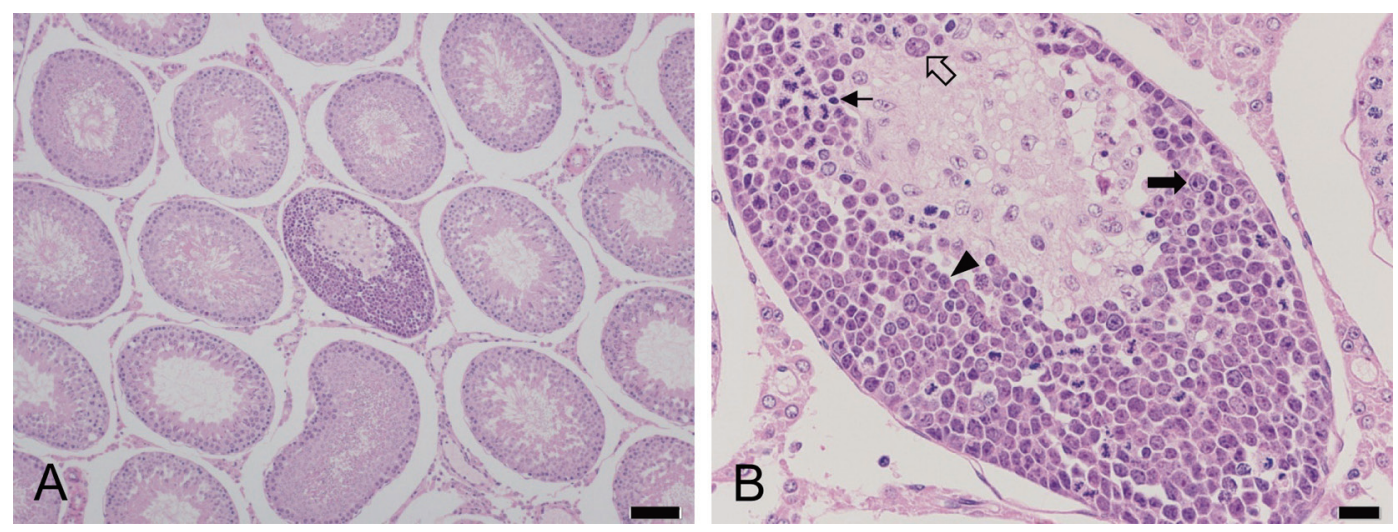

Fig. 1. Histopathological features of an intratubular seminoma in case 1. (A) The tumor cells appear confined to one seminiferous tubule. (B) Higher magnification of Fig. 1A. Intermediate-sized (arrowhead) tumor cells are predominant, and the mitotic figures are numerous. Small-sized (small arrow), large-sized (large arrow) and binucleated (open arrow) tumor cells are occasionally observed. HE stain. Bars $=100 \mu \mathrm{m}(\mathrm{A})$ and $20 \mu \mathrm{m}(\mathrm{B})$.
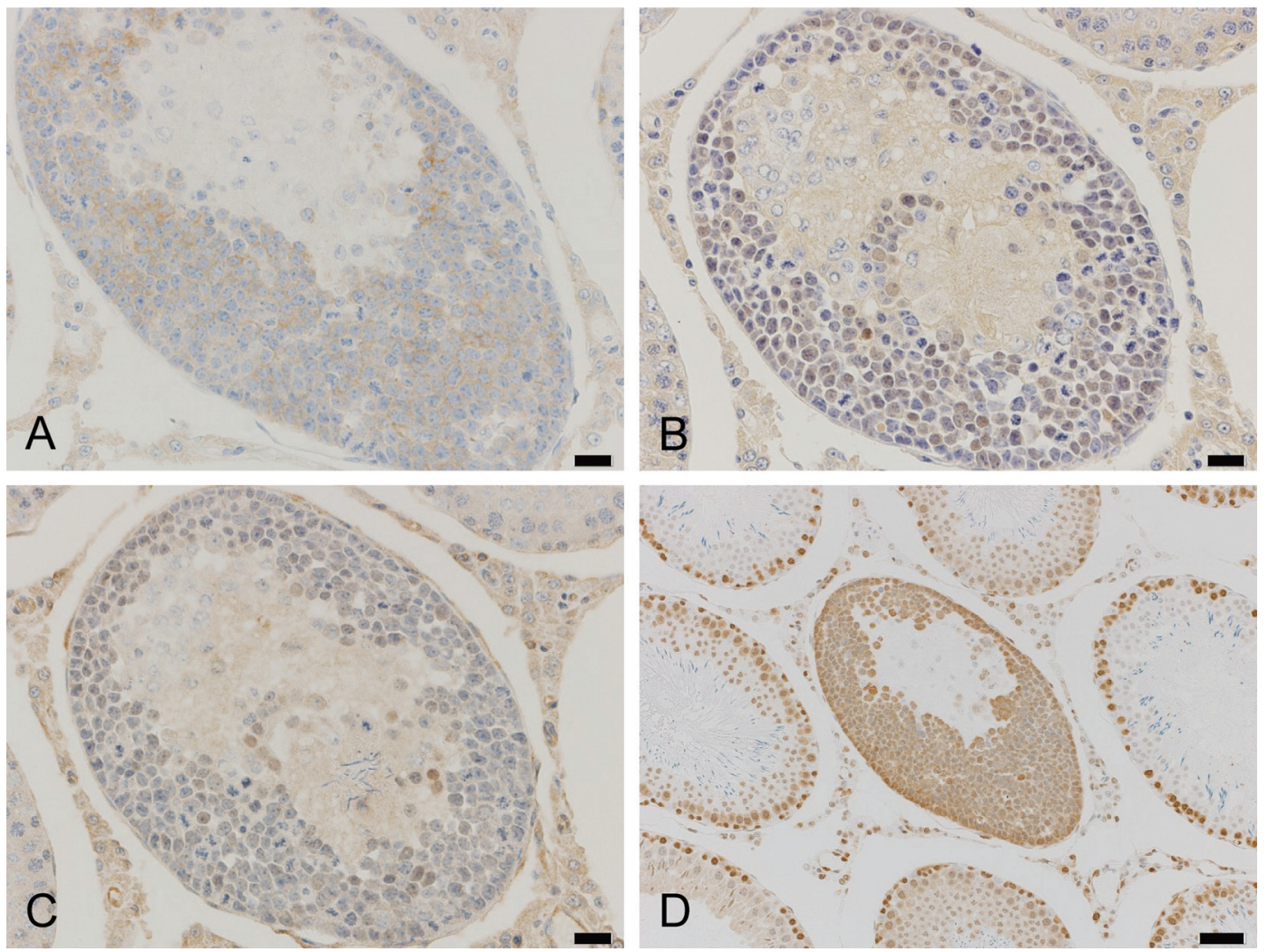

Fig. 2. Immunohistochemistry of the tumor-affected tubule in case 1. (A) c-kit, (B) NSE, (C) VASA and (D) PCNA. Cytoplasm of the tumor cells is weakly positive for c-kit. Nuclei of the tumor cells are weakly positive for NSE and VASA, while PCNA shows strong positivity. Bars $=20 \mu \mathrm{m}(\mathrm{A}, \mathrm{B}$ and $\mathrm{C})$ and $50 \mu \mathrm{m}(\mathrm{D})$.

and some tubules with regenerating germ cells coexisting with atypical cells exhibited bizarre mitoses (Fig. 3D).

These 2 cases were observed in treated rats from 2 different toxicity studies (case 1, compound A; case 2, compound $\mathrm{B}$ ). There were no other proliferative lesions in the testes or any other organs in any other dosed animals in both toxicity studies, which included rats from interim and ter- minal sacrifice groups (4-, 12- and 26-week toxicity groups and a 4-week recovery group following 26-weeks of dosing) in the case 2 toxicity study. Compounds A and B were different in structure and pharmacology and had no genotoxicity. Moreover, in the 13-week rat toxicity study for a compound A analog, no proliferative lesions were observed. Therefore, we concluded that the seminomas were both in- 

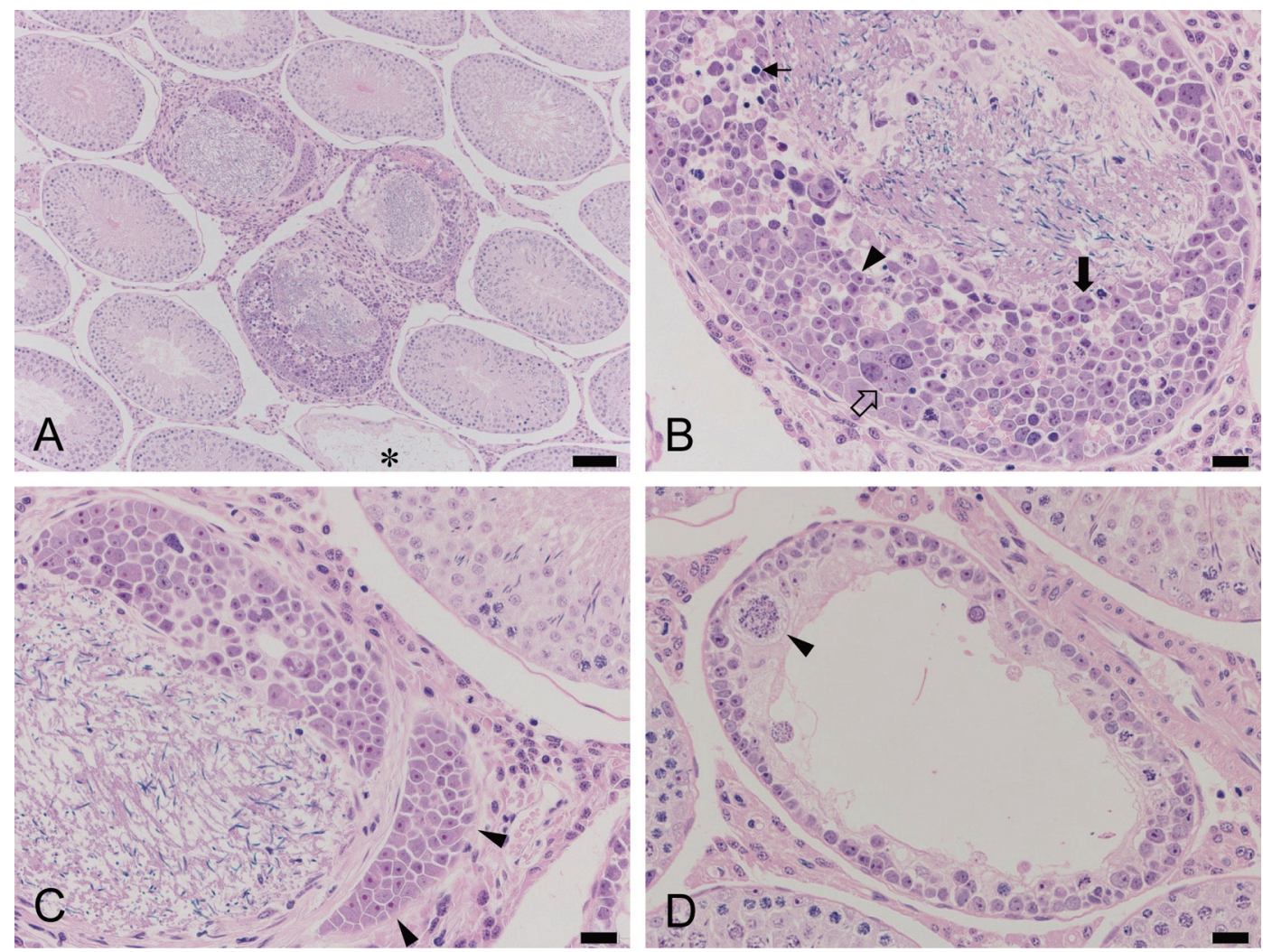

Fig. 3. Histological findings of the intratubular seminoma and tubular atrophy in case 2. (A) The proliferative pattern of the cells is similar to that in case 1 . The tubules are surrounded by macrophages and adjacent to an atrophic tubule $(*)$. (B) Higher magnification of Fig. 3A. The predominant tumor cells are medium (arrowhead) to large in size (large arrow), anaplastic and show numerous mitoses. The tubules contain small-sized tumor cells (small arrow), multinucleated giant (open arrow) tumor cells, erythrocytes and spermatozoa. (C) Higher magnification of Fig. 3A. The aggregated anaplastic tumor cells (extension-like appearance) appear to be surrounded by the basement membrane (arrowhead). (D) Regenerating germ cells (spermatogonia and early spermatocytes) coexisting with atypical cells exhibiting bizarre mitoses (arrowhead) in a seminiferous tubule. HE stain. Bars $=100 \mu \mathrm{m}(\mathrm{A})$ and $20 \mu \mathrm{m}(\mathrm{B}, \mathrm{C}$ and $\mathrm{D})$.

cidental lesions.

In human testicular pathology, various intratubular neoplasms are reported as IGCNU (intratubular germ cell neoplasia, unclassified), seminoma, spermatocytic seminoma, embryonal carcinoma, choriocarcinoma, teratoma, Sertoli cell tumor, metastatic tumors and so on ${ }^{8,12,13}$. IGCNU consists of enlarged cells with clear cytoplasm aligned along the basal portion of the seminiferous tubules and refers to a precursor lesion that can develop into all types of invasive germ cell tumors of the adult testis, with the exception of spermatocytic seminoma. The typical seminoma is composed of sheets of uniform cells divided into poorly demarcated lobules by delicate septa of fibrous tissue containing a moderate amount of lymphocytes. Seminoma cells usually display a lightly eosinophilic to clear cytoplasm because of the presence of glycogen, which is demonstrable by PAS staining ${ }^{9,}{ }^{10}$. On the other hand, spermatocytic seminoma is a rare germ cell tumor distinct from classical seminoma, and it is thought that spermatocytic seminomas originate from a postnatal germ cell, with slight predominance for the spermatogonial stem cell ${ }^{13-15}$. The cells of the spermato- cytic seminoma are more polymorphic than classical seminoma, and three types of cells are described: small-, intermediate- and large sized cells that are either uninucleate or multinucleate. The cytoplasm of spermatocytic seminoma cells is eosinophilic to amphophilic and does not contain glycogen ${ }^{9,10}$. Although there is considerable overlap, most patients with spermatocytic seminoma are older than those with classical seminoma. The prognosis of spermatocytic seminoma is remarkably good, with a very low tendency for metastasis. The anaplastic variant of spermatocytic seminoma is extremely rare, but the presence of an anaplastic component does not seem to have an impact on the excellent prognosis ${ }^{16-18}$.

In case 2, we found some intratubular proliferation of anaplastic cells with hemorrhage (presence of erythrocytes) and spermatozoa, which were surrounded by granulation tissue, so we concluded the granulation tissue was a response to the intertubular sperm (sperm granuloma). Moreover, aggregations of the anaplastic tumor cells were found adjacent to the affected tubules. Unfortunately we did not perform PAS staining, but the aggregations appeared to be surround- 
ed by the basement membrane. Therefore, we concluded the lesion showed neither microinvasion nor focal intertubular growth of the tumor cells but was part of a distorted tubule. At any rate, these tumor-affected tubules were all adjacent to each other, and it was speculated that the affected tubular profiles were convolutions of the same tubule. Moreover, in case 2, many atrophic tubules or regenerative seminiferous epithelial cells were scattered throughout both testes, and some regenerative tubules exhibited bizarre mitoses. There was no clear evidence to clarify tumorigenesis in both cases; however, in case 2 , it was speculated that a change in the germ cells in the atrophic tubules might have been associated with the tumorigenesis.

Immunohistochemically, the tumor cells in case 1 were weakly positive for c-kit, NSE and VASA but were negative for S100, PLAP, vimentin, AE1/AE3 and podoplanin. The results for $\mathrm{S} 100$ were unexpected considering the previous reports by Kerlin et $a l^{3}$ and Nyska et al. ${ }^{6}$, which reported positive immunoreactivity with S100 in both cases of seminoma and spermatic seminoma in rats. In human cases, both seminoma and spermatocytic seminoma are negative for S100. The immunohistochemical result for our rat case was also negative for S100 and closely conformed to human spermatocytic seminoma, as shown in Table $2^{19-30}$.

McConnell et al. reported that all seminomas in rodents should be considered malignant based on the growth patterns and clinical history in other species, including $\operatorname{man}^{31}$. Recently, however, the International Harmonization of Nomenclature and Diagnostic Criteria for Lesions in Rats and Mice (INHAND) guide recommended the terminology of benign seminoma for tumors that appear confined to one or a few tubular profiles and are well differentiated ${ }^{32}$. The extension-like appearance in case 2 is controversial, but we believe that at least case 1 is a benign tumor. Moreover, the diagnosis for case 1 was based not only on histological findings but also on the results of PAS and immunohistochemical staining, which appeared to be consistent with the results described for human spermatocytic seminoma ${ }^{8,10,33}$. With the exception of Leydig cell tumors, proliferative lesions of the testis are uncommon or rare in rodents ${ }^{32}$. On the other hand, germ cell tumors are common testicular tumors in humans, and while seminomas are the most common type of germ cell tumor, spermatocytic seminoma is an uncommon tumor in humans ${ }^{10}$. Therefore, it is difficult to know whether the cytological characteristics and behavior of the tumor are the same between species.

In conclusion, the present cases were diagnosed as intratubular spermatocytic seminoma based on histological and immunohistochemical findings. Our two cases are the youngest cases of spontaneous seminoma that have been described in Sprague-Dawley rats and provide valuable background control information for the occurrence of seminoma in this strain of rat.

Acknowledgments: The authors would like to thank Dr. Dianne M Creasy of Huntingdon Life Sciences, for critical review of the manuscript. Also, we would like to show our ap- preciation to Ms. Natsuko Ikeda, Ms. Takako Maegawa and Mr. Yukihiro Yanagisawa for skillful technical assistance.

\section{References}

1. Boorman GA, Rehm S, Waalkes MP, Elwell MR, and Eustis SL. Seminoma, testis, rat. In: Monographs on pathology of laboratory animals, Genital system. TC Jones, U Mohr, and RD Hunt (eds). Springer-Verlag, Berlin. 192-195. 1987.

2. Chandra M, and Riley MGI. Rarely occurring spontaneous metastasizing testicular tumors in rats. Histopathologic and ultrastructural features. Exp Toxicol Pathol. 46: 155-161. 1994. [Medline] [CrossRef]

3. Kerlin RL, Roesler AR, Jakowski AB, Boucher GG, Krull DL, and Appel WH. A poorly differentiated germ cell tumor (seminoma) in a Long Evans rat. Toxicol Pathol. 26: 691-694. 1998. [Medline]

4. Kim SN, Fitzgerald JE, and De La Iglesia FA. Spermatocytic seminoma in the rat. Toxicol Pathol. 13: 215-221. 1985. [Medline] [CrossRef]

5. Mitsumori K, and Elwell MR. Proliferative lesions in the male reproductive system of $\mathrm{F} 344$ rats and $\mathrm{B} 6 \mathrm{C} 3 \mathrm{~F} 1$ mice: incidence and classification. Environ Health Perspect. 77: 11-21. 1988. [Medline] [CrossRef]

6. Nyska A, Harmelin A, Sandbank J, Scolnik M, and Waner T. Intratubular spermatic seminoma in a Fischer-344 rat. Toxicol Pathol. 21: 397-401. 1993. [Medline] [CrossRef]

7. Takizawa S, and Miyamoto M. Observations on spontaneous tumors in Wistar Furth strain rats. Hiroshima J Med Sci. 25: 89-98. 1976. [Medline]

8. Emerson RE, and Ulbright TM. Intratubular germ cell neoplasia of the testis and its associated cancers: the use of novel biomarkers. Pathology. 42: 344-355. 2010. [Medline] [CrossRef]

9. Emerson RE, and Ulbright TM. Morphological approach to tumours of the testis and paratestis. J Clin Pathol. 60: 866-880. 2007. [Medline] [CrossRef]

10. Epstein JI. The lower urinary tract and male genital system. In: Robbins and Cotran pathologic basis of disease, 8th ed. V Kumar, AK Abbas, N Fausto, and JC Aster (eds). Saunders, Philadelphia. 971-1004. 2010.

11. Ulbright TM. Germ cell tumors of the gonads: a selective review emphasizing problems in differential diagnosis, newly appreciated, and controversial issues. Mod Pathol. 18(Suppl 2): S61-S79. 2005. [Medline] [CrossRef]

12. Young RH. Testicular tumors - some new and a few perennial problems. Arch Pathol Lab Med. 132: 548-564. 2008. [Medline]

13. Reuter VE. Origins and molecular biology of testicular germ cell tumors. Mod Pathol. 18(Suppl 2): S51-S60. 2005. [Medline] [CrossRef]

14. Stoop H, van Gurp R, de Krijger R, Geurts van Kessel A, Köberle B, Oosterhuis W, and Looijenga L. Reactivity of germ cell maturation stage-specific markers in spermatocytic seminoma: diagnostic and etiological implications. Lab Invest. 81: 919-928. 2001. [Medline] [CrossRef]

15. Waheeb R, and Hofmann MC. Human spermatogonial stem cells: a possible origin for spermatocytic seminoma. Int $\mathrm{J}$ Androl. 34: e296-e305, discussion e305. 2011. [Medline] [CrossRef]

16. Albores-Saavedra J, Huffman H, Alvarado-Cabrero I, and 
Ayala AG. Anaplastic variant of spermatocytic seminoma. Hum Pathol. 27: 650-655. 1996. [Medline] [CrossRef]

17. Dundr P, Pesl M, Povýsil C, Prokopová P, Pavlík I, Soukup V, and Dvorácek J. Anaplastic variant of spermatocytic seminoma. Pathol Res Pract. 203: 621-624. 2007. [Medline] [CrossRef]

18. Lombardi M, Valli M, Brisigotti M, and Rosai J. Spermatocytic seminoma: review of the literature and description of a new case of the anaplastic variant. Int J Surg Pathol. 19: 5-10. 2011. [Medline]

19. Biermann K, Stoop H, and Looijenga L. c-KIT protein expression does not discriminate neoplastic from non-neoplastic intratubular germ cells. Histopathology. 60: 10171019. 2012. [Medline] [CrossRef]

20. Rajpert-De Meyts E, Jacobsen GK, Bartkova J, Aubry F, Samson M, Bartek J, and Skakkebaek NE. The immunohistochemical expression pattern of Chk2, p53, p19 $9^{\text {INK4d }}$, MAGE-A4 and other selected antigens provides new evidence for the premeiotic origin of spermatocytic seminoma. Histopathology. 42: 217-226. 2003. [Medline] [CrossRef]

21. Sandlow JI, Feng HL, and Sandra A. Localization and expression of the c-kit receptor protein in human and rodent testis and sperm. Urology. 49: 494-500. 1997. [Medline] [CrossRef]

22. Cummings OW, Ulbright TM, Eble JN, and Roth LM. Spermatocytic seminoma: an immunohistochemical study. Hum Pathol. 25: 54-59. 1994. [Medline] [CrossRef]

23. Kang JL, Rajpert-De Meyts E, and Skakkebaek NE. Immunoreactive neuron-specific enolase (NSE) is expressed in testicular carcinoma-in-situ. J Pathol. 178: 161-165. 1996. [Medline] [CrossRef]

24. Niehans GA, Manivel JC, Copland GT, Scheithauer BW, and Wick MR. Immunohistochemistry of germ cell and trophoblastic neoplasms. Cancer. 62: 1113-1123. 1988. [Medline] [CrossRef]
25. Ujié T, and Monma N. An immunohistochemical study on neuron specific enolase in testicular germ cell tumors. Nippon Hinyokika Gakkai Zasshi. 82: 297-304. 1991; (in Japanese). [Medline]

26. Zeeman AM, Stoop H, Boter M, Gillis AJM, Castrillon $\mathrm{DH}$, Oosterhuis JW, and Looijenga LHJ. VASA is a specific marker for both normal and malignant human germ cells. Lab Invest. 82: 159-166. 2002. [Medline] [CrossRef]

27. Donner J, Kliesch S, Brehm R, and Bergmann M. From carcinoma in situ to testicular germ cell tumour. APMIS. 112: 79-88. 2004. [Medline] [CrossRef]

28. Soosay GN, Bobrow L, Happerfield L, and Parkinson MC. Morphology and immunohistochemistry of carcinoma in situ adjacent to testicular germ cell tumours in adults and children: implications for histogenesis. Histopathology. 19: 537-544. 1991. [Medline] [CrossRef]

29. Sesterhenn IA, Davis CJ, and Furusato B. M2A antigen (podoplanin) distribution in prepubertal and adult testes and testicular tumors. Mod Pathol. 19: 159A-160A. 2006.

30. Yu H, Pinkus GS, and Hornick JL. Diffuse membranous immunoreactivity for podoplanin (D2-40) distinguishes primary and metastatic seminomas from other germ cell tumors and metastatic neoplasms. Am J Clin Pathol. 128: 767-775. 2007. [Medline] [CrossRef]

31. McConnell RF, Westen HH, Ulland BM, Bosland MC, and Ward JM. Proliferative lesions of the testes in rats with selected examples from mice, URG-3. In: Guides for toxicologic pathology. STP/ARP/AFIP, Washington. 1-32. 1992.

32. Creasy D, Bube A, de Rijk E, Kandori H, Kuwahara M, Masson R, Nolte T, Reams R, Regan K, Rehm S, Rogerson $\mathrm{P}$, and Whitney K. Proliferative and nonproliferative lesions of the rat and mouse male reproductive system. Toxicol Pathol. 40(Suppl): 40S-121S. 2012. [Medline] [CrossRef]

33. Aggarwal N, and Parwani AV. Spermatocytic seminoma. Arch Pathol Lab Med. 133: 1985-1988. 2009. [Medline] 